\title{
A Qualitative Phytochemical Analysis and a Comparative Study of the Antibactrial Activity of Retama stalks (raetam)
}

\section{HAMZA BENSACI, LAKHDAR SEKHRI ${ }^{*}$, ABDELAALI ATMANI and AHMED TABCHOUCHE}

Laboratoire De Dynamique Interaction et Réactivité des Systèmes, Process Engineering Department, Faculty of Applied Sciences, University Kasdi Merbah, Ouargla 30000, Algeria.

${ }^{*}$ Corresponding author E-mail: sekhril@yahoo.fr

http://dx.doi.org/10.13005/ojc/320135

(Received: December 31, 2015; Accepted: March 05, 2016)

\begin{abstract}
The present work is aimed mainly to investigate and compare the antibacterial activities of methanolic, diethyl ether and ethyl acetate extracts of retama on Escherichia coli, Salmonella, Proteus mirabilis and Staphylococcus aureu using well difusion method. The results of study showed a significant effect on all bacterial species except Proteus mirabilis. The preliminary test of retama constituents revealed the presence of active material : Resins, Volatil oils, Coumarins, Terpenes, Phenols, Tannins, Alkaloids, Saponins, Cardiac glycosides, and Flavons. The highest Inhibition rate of Salmonella is $16 \mathrm{~mm}$ at the concentration $100 \mathrm{mg} / \mathrm{ml}$, while the lowest inhibition rate was $8 \mathrm{~mm}$ for Escherichia coli at concentration $1 \mathrm{mg} / \mathrm{ml}$ in methanolic extract. The results obtained in the present study suggest that the retama stalks (broom broom) can be used in treating deseases caused by the tested organisms. Further chemical and pharmacological investigations may be carried out to isolate and identify the chemical constituents in the selected plants responsible for the antimicrobial activity.
\end{abstract}

Key words : phytochemical analysis, sretama talks, salmonella, antibactrial activity.

\section{INTRODUCTION}

The urinary tract infection is the most common bacterial diseases in children, as it ranks second in terms of spreading infection after respiratory tract. ${ }^{1-4}$ The urinary tract infection comes usually from attacking microorganisms urinary system that are mostly negative gram bacteria, from digestive system, as most of the infections at urinary system caused by bacteria intestinal Enterobacteriaceae including Bacillus colon Escherichia coli, which occupies a leading position among the races of this family. ${ }^{5}$ As well as other pathogens include Staphylococcus aureus and Streptococci and sometimes as types fungus Candida fungal. ${ }^{6}$

The virulence of bacteria attacking and vulnerability to the host of fundamental importance 
in the occurrence and development of the infection, which relies on a series of interactions between pathogen and host. The infection of the urinary tract occurs as a result of excessive growth of the bacteria with high virulence in the urinary tract and then the displacement of these bacteria to the bladder, and may include the urethra injury, ureters and bladder and kidney. ${ }^{7,8}$ Most bacterial infections are treated with antibiotics, but at present time the natural herbal treatments (folk medicine) has spread dramitically without resorting to drugs and synthetic materials.

Therefore, we have chosen the study of medicinal retama plant (broom plant), a desert plant, it reaches a hight of more than 2 meters. It has small leaves, rapid falling (precipitation), to reduce the transpiration process, flowers butterfly shaped white Color and cup pink color purple, oval-shaped fruits contain one seed. Moreover we have chosen to study the stalks and flowers of this medicinal plant because of the availibility of year-round and represents the most of the plant size. This plant used in the treatment of allergies, stopping the bleeding and to treat the wounds. However, due to the appearance of new strains of the bacteria and the weakness of chemotherapeutics and antibiotic resistance exhibited by pathogens has led to the screening of several medicinal plants for their potential antimicrobial activity. ${ }^{8-10}$ An increasing number of reports dealing with the assessment of antimicrobial effects of different extracts of various medicinal plants are frequently available. ${ }^{11-15}$

The aim of of this study was to evaluate the activity of aquous and alcoholic, diethyl ether and ethyl acetate extracts against several Gram-positive and Gram-negative bacterial strains in vitro.

\section{MATERIALS AND METHODS}

Fresh plant/plant parts : retama plant was collected randomly from the Lamniaa desertGhardaia Algeria in November 2013. The medicinal plant was deposited at Laboratoire de Dynamique Interaction et Réactivité des Systèmes, Department of Process engeneering, Faculty of Applied Sciences, University of Kasdi Merbah-Ouargla. Fresh stalks plant material was washed under running tap water, air dried under dark and then homoggenized to fine powder and stored in closed container away from light and moisture.

\section{Preliminary Phytochemical Analysis}

Qualitative Phytochemical analysis of the stalks plant powder was determined as follows :

Resins (200 mg plant material in $10 \mathrm{ml}$ distilled water, filtered) ; a $10 \mathrm{ml}$ filtrate $+4 \% \mathrm{HCl}$, the apearance of turbidity indicated the presence of Resins. Volatile oils (200 mg plant material in $10 \mathrm{ml}$ distilled water, filtered), then a filter paper saturated by the filtrate and exposed to the UV rays, bright rose color indicated the presence of Volatile oils. ${ }^{15}$ Coumarins : In a test tube was placed $1 \mathrm{~g}$ in $10 \mathrm{ml}$ of distilled water, then covered with filter paper after being soaked in a diluted solutin of $\mathrm{NaOH}$. The test tube was placed in boil water bath for a few minutes and then exposed to UV rays, yellow-green indicated the presence of Coumarins. ${ }^{17}$ Terpenes (LiebermannBurchard reaction : $200 \mathrm{mg}$ plant material in $10 \mathrm{ml}$ chloroform, filtered); a $2 \mathrm{ml}$ acetic anhydride + conc. $\mathrm{H}_{2} \mathrm{SO}_{4}$. Blue-green ring indicated the presence of Terpenes. ${ }^{18}$ Phenols (200 mg plant material in $10 \mathrm{ml}$ distilled water, filtered) ; a $2 \mathrm{ml}$ filtrate $+2 \mathrm{ml} \mathrm{FeCl}_{3}$, blue-Green precipitate indicated the presence of Phenols. ${ }^{18}$ Tannins (200 mg plant material in $10 \mathrm{ml}$ distilled water, filtered) ; a $2 \mathrm{ml}$ filtrate $+2 \mathrm{ml} \mathrm{FeCl}_{3}$, blue-black precipitate indicated the presence of Tannins. Alkaloids (200 mg plant material in $10 \mathrm{ml}$ methanol, filtered) ; a $2 \mathrm{ml}$ filtrate $+1 \% \mathrm{HCl}+$ steam, $1 \mathrm{ml}$ filtrate +6 drops of Mayor's reagents/Wagner's reagent/Dragendroff reagent, creamish prcipitate/ brownish-red precipitate/orange precipitate indicated the presence of respective alkaloids. ${ }^{20}$ Saponins (frothing test : $0.5 \mathrm{ml}$ filtrate $+5 \mathrm{ml}$ distilled water) ; frothing persistence indicated the presence of saponins. Cardiac glycosides (Keller-Kilani test : a 2 $\mathrm{ml}$ filtrate $+1 \mathrm{ml}$ glacial acetic acid $+\mathrm{Fe}_{3}+$ conc . $\mathrm{H}_{2} \mathrm{SO}_{4}$ ) ; green-blue color indicated the presence of cardiac glycosides. Steroids (Liebermann-Burchard reaction : $200 \mathrm{mg}$ plant material in $10 \mathrm{ml}$ chloroform, filtered) ; a $2 \mathrm{ml}$ acetic anhydride + conc. $\mathrm{H}_{2} \mathrm{SO}_{4}$. Blue-green ring indicated the presence of steroids. Flavonoids (200 mg plant material in $10 \mathrm{ml}$ ethanol, filtered) ; a $2 \mathrm{ml}$ filtrate + conc. $\mathrm{HCl}$ + magnesium ribbon, pink-tomato red color indicated the presence of flavonoids. ${ }^{21}$ Flavons : $10 \mathrm{ml}$ of solution of plant powder in ethanol $(50 \%)$ was added to $10 \mathrm{ml}$ of $\mathrm{KOH}$ soltion $(50 \%)$, and then equal amounts of this 
solution and extracted plant were mixed, yellow color, indicated the presence of Flavons. ${ }^{22}$

\section{Extraction of plant material}

Each extrat was prepared by soaking $200 \mathrm{~g}$ of the plant powder in a mixture of $\mathrm{EtOH} / \mathrm{H}_{2} \mathrm{O}(70 / 30)$ evaporated under reduced pressure. The second extract was prepared by soaking $200 \mathrm{~g}$ in diethyl ether, and the third extract was prepared by soaking $200 \mathrm{~g}$ in ethyl acetate. Each of the resulting extracts was diluted with distilled water and left overnight. The ethanolic filtrates were subjected to extraction by various solvents with increasing polarity (petroleum ether, dichloromethane, ethyl acetate, and butanol). All organic phases were separated and evaporated. The rsulting residue was stored at $4^{\circ} \mathrm{C}$.

\section{Microorganisms}

All bacterial standard strains : Escherichia coli ATCC 25922, Staphylococcus aureus ATCC 25923, Proteus mirabilis and Salmonella were obtained from Colonel Chaabani Hospital, Lamniaa, W. Ghardaia. ALGERIA.

\section{Preparation of the bacterial culture media}

3.7 of muller Hilton agar was mixed with hot distilled water and autoclaved at $121^{\circ} \mathrm{C}$ and 2 atm for 15 minutes. After autoclavingit was allowed to cool to $45^{\circ} \mathrm{C}$ in a water bath. Then the medium was poured into sterillized petri dishes with a uniform depth of approximately $5 \mathrm{~mm} .^{20}$

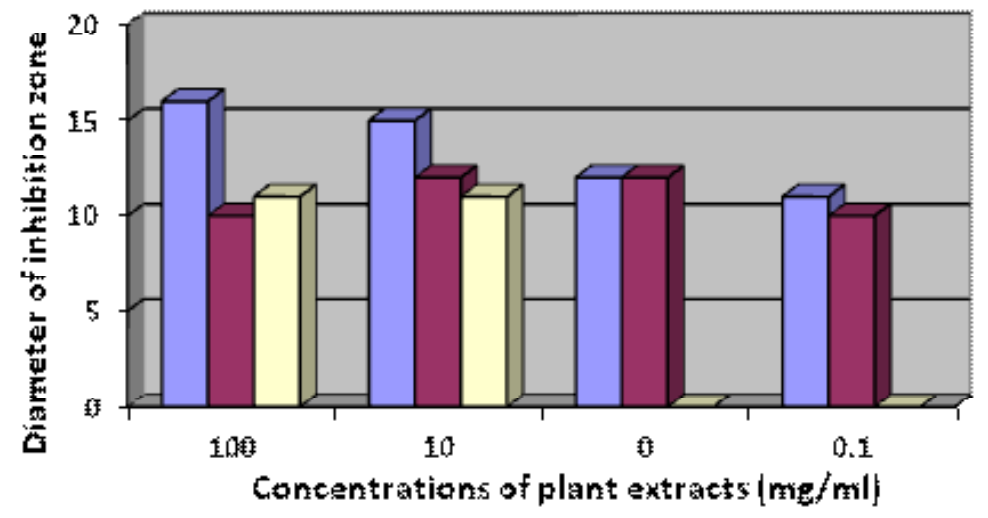

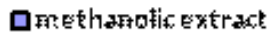 \\ 口dieffiylextract \\ 口efhyl axetake extrat}

Fig.1 : The influence of three extract concentration of Retama plant vs the inhibition diameter on Salmonella

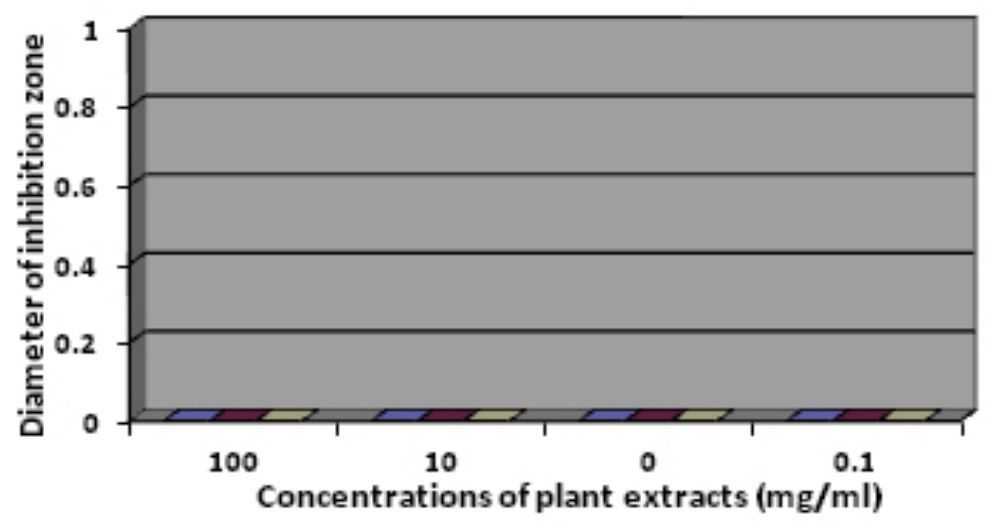

$$
\begin{aligned}
& \square \text { methanolic extract } \\
& \square \text { diethyl extract } \\
& \square \text { ethyl acetate extract }
\end{aligned}
$$

Fig.2 : The influence of three extract concentration of Retama plant vs the inhibition diameter on Proteus mirabilis 
Preparation of plant extract impregnated discs Whatman $\mathrm{N}^{\circ} 1$ filter paper was used to prepare discs of $6 \mathrm{~mm}$ in diameter. They were sterillized by autoclaving and then dried during the autoclaving cycle. The discs were then impregnated with extract of the plants. ${ }^{23}$

\section{Disc diffusion method}

Disc diffusion method for antimicrobial susceptibility test was carried out according to the standard method by Kirby-Bauer to assess the presence of antibecterial activities of plant extracts. ${ }^{22}$ A bacterial suspention adjusted to $0.5 \mathrm{McF}$ arland standard $\left(1.5 \times 10^{8} \mathrm{CFU} / \mathrm{ml}\right)$ was used to inoculate Mueller Hinton agar plates evenly using a sterile swab. The discs impregnated with the plant extracts were placed individually on the Mueller Hinton agar surface. The discs were spaced far enough to avoid both reflection waves from the edges of the petri disces and overlapping rings of inhibition. The plate was then incubated at $37^{\circ} \mathrm{C}$ for 18 hours in inverted position to look for zones of inhibition. Zones of inhibitions produced by the sensitive organisms were demarcated by a circular area of clearing around the plant extract impregnated discs. The diameter of the zone of inhibition through the center of the disc was measured to the nearest millimeter. The rsulting residue of all extracts stored at $4^{\circ} \mathrm{C}$ were tested at concentrations of $10^{-1}, 10^{-2}, 10^{-3}$ and $10^{-4} \mathrm{~g} / \mathrm{ml}$ and were prepared in DMSO.

\section{RESULTS AND DISCUSSION}

The preliminary phytochemical analysis of the crude powder of Retama plant collected showed that the stalks of Retama plant contains many active ingrediants: Coumarins, tannins, volatile oils, terpenes and alkaloids, one of the

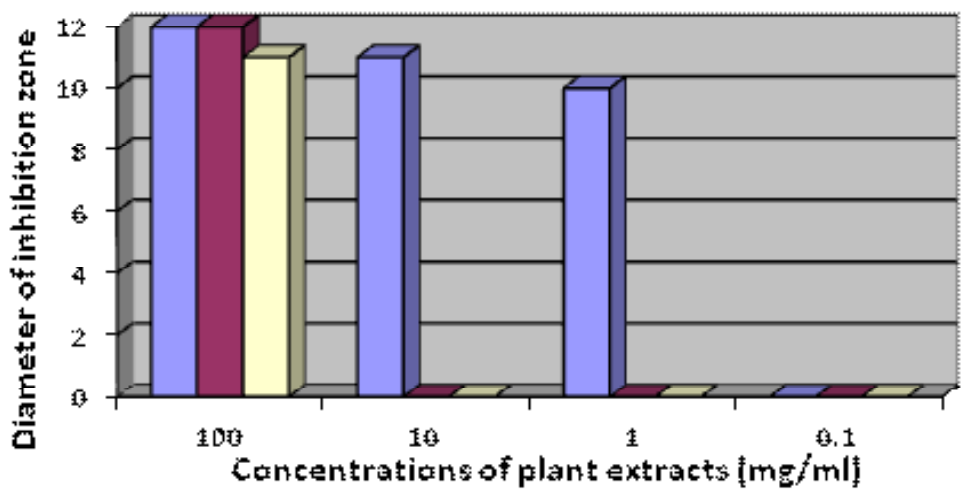

口।metlal:क|lis extract

口(tiett) by extraxt

Qertßql atetate extract

Fig.4 : The influence of three extract concentration of Retama plant vs the inhibition diameter on Staphylococcos aureus

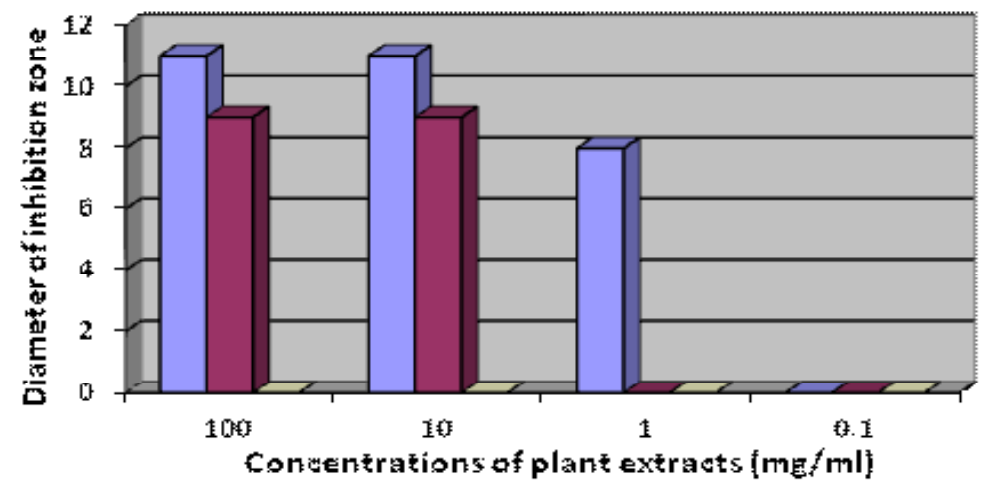

口methafulitextrat

口đİeffylextract

口enfyll axcetafe extract

Fig. 3 : The influence of three extract concentration of Retama plant vs the inhibition diameter on Proteus Escherichia coli 


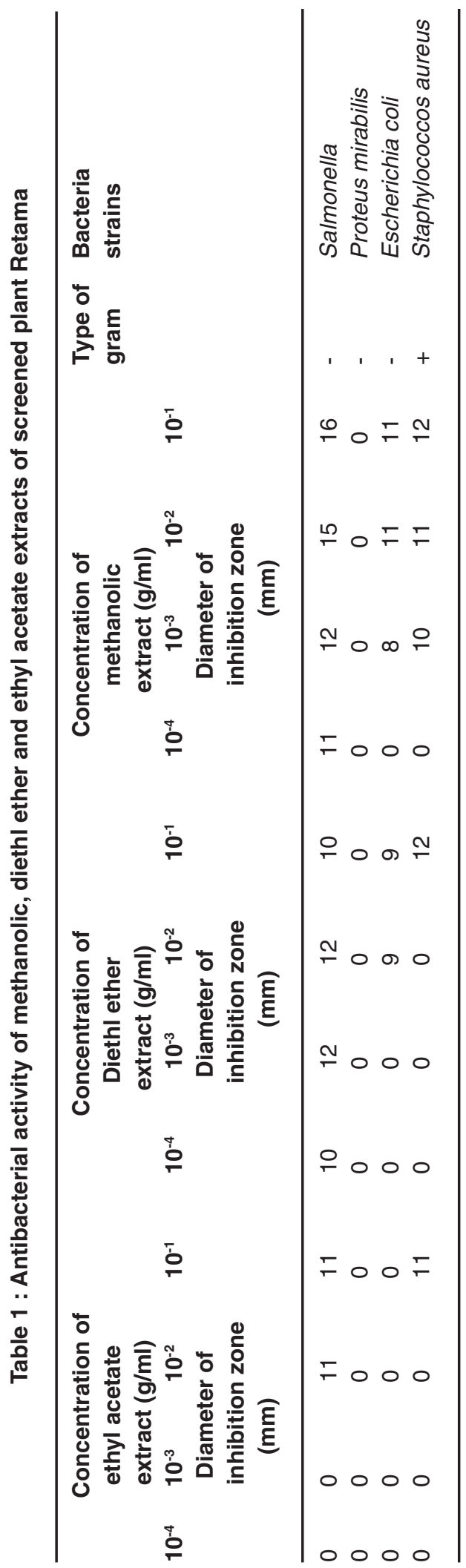

antioxidants of the bacteria responsible for the effect of microbs, also contains flavonoids including glycosides antioxidant and phenols and saponins. As for the nature of the extracts were characterized by strength viscous dark green color and aromatic smell, due to the emergence of green chlorophyll pigment and material xanthine. The aromatic smell of Retama plant can be attributed to the volatile oils, also contains vegetarian jelly and glues. ${ }^{24}$

Results for antibacterial activity as obtained with Retama plant revealed that the three different extracts tested in vitro by agar disc difusion against 4 bacterial species. Table 1 : summarizes the microbial growth inhibition of tested extracts of this plant that showed significant bacterial activity against all the bacteria tested (Escherichia coli, Salmonella, and Staphylococcus aureu) except Proteus mirabilis where the maximum activity was recorded against Salmonella and a maximum inhibition diameter of $16 \mathrm{~mm}$ with the methanolic extract at concentration $10^{-1} \mathrm{~g} / \mathrm{ml}$. On the other hand the three extracts were ineffective against Proteus mirabilis.

Moreover the ethyl acetate extract showed no effect against Escherichia coli, Proteus mirabilis and Staphylococcus aureu at different concentrations. Moderate inhibition was recorded with the methanol extracts at $10^{-3}$ against Escherichia coli. As far as the concentration of $10^{-4}$ is concerned the three extracts exhibits no actions against Escherichia coli, Proteus mirabilis and Staphylococcus aureu. However moderate effects against Salmonella are recorded at this concentration. Figures-1, 2, 3, and 4 showed the influence of the extract concentration on the growth of the the bacteria tested.

The increase in the effect of the alcoholic extract of the retama plant may be due to the extract effect on the permeability of the cell membrane and the function of the bacterial cell. The activity of the extracts of this plant can be attributed to the presence of phenolic compounds that have inhibitory efficacity on the positive and negative gram bacteria.

Generally, the three extracts of this plant are more or less effective towards the tested bacteria and methanolic extracts are more potent compared to ethyl acetate and Diethyl ether extracts. 


\section{CONCLUSION}

This study underscored the antimicrobial activity of one chenopodiaceae species namely: Retama using three different solvents : Diethyl ether, Ethyl acetate, and Methanol with increasing polarity against four bacteria strains. This medicinal plant averred to be effective against three types of gram negative bacteria : Escherichia coli, Salmonella, and Proteus mirabilis and one type of gram positive Staphylococcus aureus. The results partially justify the claimed uses of the selected plant in the traditional system of medicine to treat various infectious diseases caused by the microbes. Further chemical and pharmacological investigations may be carried out to isolate and identify the chemical constituents in the selected plant responsible for the antimicrobial activity.

\section{ACKNOWLEDGMENT}

The authors are thankful to the staff of microbiological laboratory, Colonel Chaabani Hospital, Lamniaa, W. Ghardaia. ALGERIA, for their assistance and providing the necessary facillities to carry out this work.

\section{REFERENCES}

1. Chakra borty, P., Urinary tract infection: Text book of microbiology st. ed-new central book agency, Calcutta, India, 1996.; 577 -581

2. Funfstuck, R., Smith, J. W., Tschape, $H$. and Stein, G., pathogentic aspects of uncomplicated urinary tract infections, recont advances. clin. Neph, 1997. 47(1):13-18

3. Lettgen, B., Urinary tract infections in childhood old and aspects. klin. pediatr; 1993.205 (5): 325- 331

4. Strffon, R . A., Urinary tract infection problem in diagnosis and management. Med. Clin . North Am, 1974. 58(3) :545 - 553.,

5. Egorove, N. S., Antibiotics scientific Approach .Mirpublis hers Moscow. Antimicrob chemoth (1985).

6. Rushton, H. G., Urinary tract infections in children, Epidemiology, Evaluation and management . Pediatr. Uro , 1997. 44 (5) : 1133- 1169

7. Nickel, J. C., Costerton, J. W., Mcleam, R. J. and Alson, M., Bacterialbio films, Influence on the pathogenesis, diaqnoses and treatment of Urinary tract infection, J-Antimicrob chemoth. (1994).

8. Winberg, J., urinary tract Infections in children curr., opin . Inf. Dis., 1990.3: 55-61.

9. Colombo, M. L., Bosisio, E., Pharmacological activities of Cheldonium majus $L$ (Papaveraceae). Pharmacol Res., 1996.33 : 127,

10. Iwu, M.W., Ducan, A. R., and Okunji, C. O., New antimicrobials of plant origin. In ; Janick J. ed. Perspictives on new Crops and new Uses. Alexandria, VA ; ASHS Press, 457 (1999).

11. Benkeblia, N., Antimicrobial activity of essential oil extracts of various onions (allium cepa) and garlic (Allium stivum). LebensmWiss u-Technol, 2004. 37 : 263,

12. Babamer, Zohra Y., Sekhri, L., Al-Jaber, Hala I., Al-Qudah, Mahmoud A., and Abu Zarga, Musa $\mathrm{H}$. Journal of asian Natural Products Research, 2012. 1,

13. Ashakkumar, R., and Ramaswamy, M. J., Chem Bio Physci Sec., 2013. 3(2) : 1279

14. Bindu. J., Anjali. K., and Vibhor K.j., Asian Journal of Biochemical and Pharmaceutical research, 2011. 2(1) : 437

15. Mukundam, B., Shagufa, A., and Swarnamoni, D. A., Asian J Pharm Bio res., 2012. 2(3) : 183

16. Babamer Zohra Y., Sekhri, L., Al-Jaber, Hala I., Al-Qudah, Mahmoud A., and Abu Zarga, Musa $\mathrm{H}$. Journal of asian Natural Products Research, 2012. 1-7,

17. Geisman, T. A., Chemistry of Havonoids compounds. Macmillan Co. New York. 1962.90101

18. Al-Abid, M. R., Zurrzusamme mse turungder Abschla B membrane in Phoenix dactylifera. Wurzburg University. Wurzburg, F. R. of Germany, 1985.153-140

19. Winberg, J., Urinary tract infections in children curr. Opin. Inf. Dis., 1990. 3 : 55-61

20. Harbone, J. (1973). Phytochemical methods. Chapman and Hall. London. 
21. Oguyemi AO. In : Sofowora A. ed. Prodeedings of a Conference on African Medicinal plants. Ife-Ife : Univ Ife, 1979. 20-22

22. Harbone, J. B., (1984). Phytochemical methods. A guide to modern techniques of p lant analysis. 2nd ed., Chapman and Hall. London. P: 288.

23. Swarnamoni, D., Mukundam, B., and Shagufa, A., Asian Pharm Clin Res., 2013.6
(4) : 136-139

24. Worshiper, Kausar Fouad, Anti-bacterial activity and anti-Candida in the volatile oils of some medicinal plants in Saudi Arabia-microbiology, neighborhoods, aureus Bacillus, Escherichia coli outside the body of the organism. Majester Thesis, Faculty of Education, University of Riyadh (2008). 